\title{
SEC23B Gene
}

National Cancer Institute

\section{Source}

National Cancer Institute. SEC23B Gene. NCI Thesaurus. Code C97933.

This gene plays a role in vesicular transport. 